\title{
Interpersonal Metaphor in Legal Discourse: Modality in Cross-examinations
}

\author{
Jiezhen Dong \\ Guangdong Pharmaceutical University, Guangzhou, China
}

\begin{abstract}
Halliday's Systemic Functional Linguistics (SFL) has been widely applied to different discourse analysis but the courtroom discourse analysis has seldom been touched upon. This article presents a modality analysis of the utterances between the lawyer and the witness within the interpersonal meta-function of Systemic Functional Linguistics framework. Applying the theory of interpersonal metaphors to the analysis of the discourse of cross-examination, the article evaluated the relationship between the different types, orientations and values of modality used in court and the chances of taking the powerful linguistic position and gaining the trust of the jury. The results of present study contribute to readers' understanding of the techniques for the lawyer and the witness to examine or reply successfully.
\end{abstract}

Index Terms - cross-examination, modality, orientation, types, values

\section{INTRODUCTION}

Law is an overwhelmingly linguistic institution. The world of law begins with speech and is made and announced with words. The legal actions and the legal provisions are related to the thoughts, public speeches and debates. With the rapid development of the law science, linguists attach more and more importance to the linguistic study in the legal field. Some of them fight for justice with speech and others made a great amount of researches of the specific cases. The researches involve many subjects, such as Phonetics, Sociolinguistics, Psycholinguistics, Pragmatics, Rhetoric and Graphology.

The study of courtroom discourse, as an important branch of Forensic Linguistics, is still in its infancy either at home or abroad. Courtroom discourse includes opening statements, courtroom testimony, closing arguments, examination and so on. Among them, lawyer-witness examination, especially cross-examination, is the most important part of courtroom discourse analysis. From the different research methods, the courtroom discourse analysis in these decades can be divided into four types: Rhetoric, Sociolinguistics, Conversation Analysis and Pragmatics. This article explores power in the discourse of cross-examination, from the perspective of the modality system. Linguistic power can be defined as different social positions in certain context of situation, which is mainly realized by means of controlling or losing control of language. Mood and modality are the grammatical means to control or lose control of language. The article focuses on the modality system.

Functional linguistics views modality as a complex area of English grammar. It concerns with the different ways by which a speaker expresses his attitude toward or opinion about the truth of what he says. In Halliday's (1994) opinion, modality is the intermediate degrees between the positive and negative poles. In fact, linguistic realizations of modality may be adjectival, adverbial or modal verbs, the latter probably the most common. In addition, modality can also be realized by nouns or prepositional phrases through the process of nominalization or even by full clauses and so on. It is hoped that SYSTEMIC FUNCTIONAL LINGUISTICS is a comprehensive descriptive and interpretive framework for courtroom discourse analysis.

\section{Methodology}

Halliday (1994) argues that "modality refers to the area of meaning that lies between yes and no: the intermediate ground between positive and negative polarity"(p. 356).

Halliday referred modality as the intermediate degrees between the positive and negative poles. According to the distinction between propositions ("information", i.e. statements and questions) and proposals ("goods \& services", i.e. offers and commands), modality is correspondingly categorized into modalization and modulation. When we discuss the modality of propositions (statements and questions), we are dealing with "modalization", speaker's assessments of probability and usuality. But when we discuss the modality of proposals (commands and otters), then we are dealing with "modulation", the speaker's assessments of obligation or inclination. The types of modality can be set out in the following figure: 


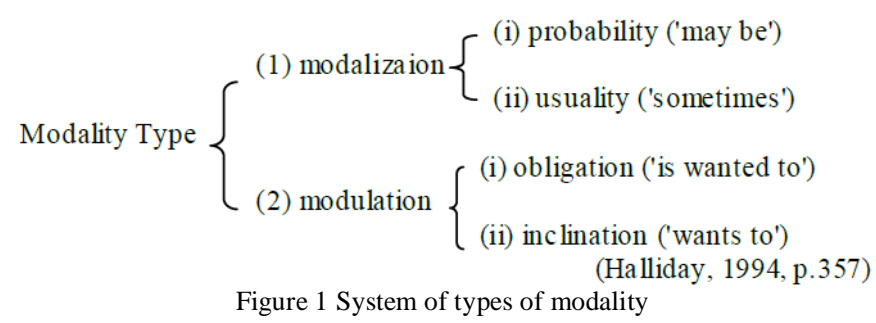

To analyze the degree and scales of modality, Halliday (1994) established three basic values which are "attached to the modal judgment: high, median and low" (p. 358). The values of modality are summarized as the following:

TABLE I

THREE 'VALUES' OF MODALITY

\begin{tabular}{|l|l|l|l|l|}
\hline & Probability & Usuality & Obligation & Inclination \\
\hline High & certain & always & required & determined \\
\hline Median & probable & usually & supposed & keen \\
\hline Low & possible & sometimes & allowed & willing \\
\hline
\end{tabular}

As for modal verbs, Halliday attaches values to them in the following way:

High: must ought to need has to is to

Median: will would shall should

Low: may might can could

(Halliday, 1994, p.362)

When the communicators want to modalize their messages, they have to make selections in the modality system. While the communicators are choosing some type of modality they want to use and some kind of value they want to set to their messages, they also have to take the orientation of modality into considerations. The orientation plays the role of determining how explicitly the communicators want to commit themselves to the propositions or proposals. Halliday classifies the orientation into four types:

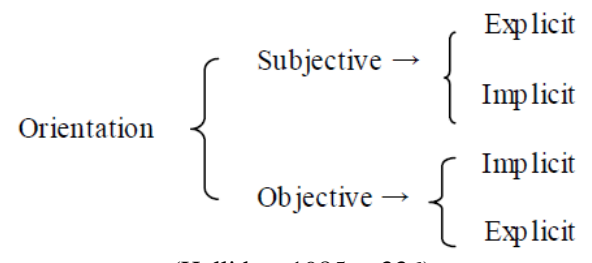

Figure2 System of orientations in modality

In conclusion, according to the discussion above, the system of modality can be shown in the following figure:

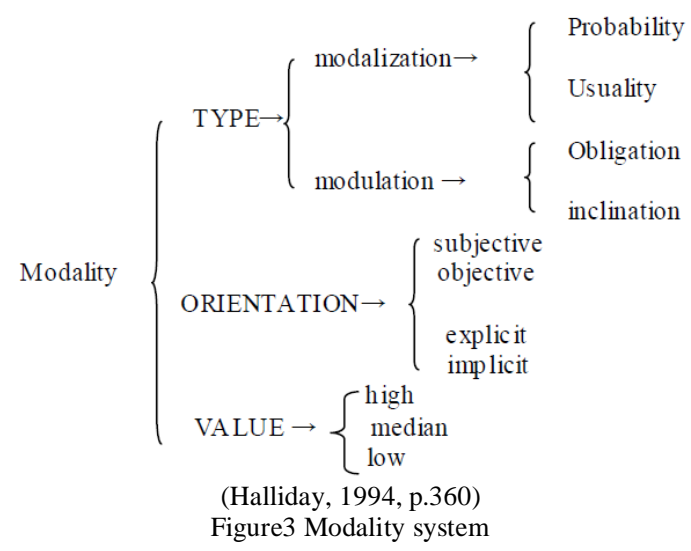

To sum up, speakers can move between the positive and the negative pole in modality system. With the help of the modality system, the communicators are able to "modify" their messages. The speakers have to take type, value, and orientation into consideration, in order to make the communications more successful, when selecting the system of modality.

Functional grammar defines modality as "the speaker's judgment of the probabilities, or the obligations, involved in what he is saying" (Halliday, 1994, p.75) and regards it as the main semantic carrier of interpersonal meaning, without 
limiting modality within single utterances. As a matter of fact, it broadens the concept of modality to the discourse level. It gives us a new perspective to analyze the courtroom discourse.

\section{FINDINGS AND DisCUSSIONS}

Court is a place for the two opposite sides to compete for power, without hiding their attitudes towards the fact. There are two purposes of cross-examinations. One is to elicit favorable testimony. This involves getting the witness to admit those facts that support your case in chief and are consistent with your theory of the case, themes, and labels. The other one is to conduct a destructive cross. This involves asking the kinds of questions that will discredit the witness or his testimony so that the jury will minimize or even disregard them. Since a destructive cross is one that attempts to discredit a witness or his testimony so that the jury will minimize or even disregard what the witness has stated, some special techniques are needed to achieve this goal. If we analyze the utterance in the cross-examinations, it is not difficult for us to find that the use of modality plays a very important role in the second purpose of cross-examinations. It can even decide the lawyer's and the witness' credibility for the judge and the panel. The more objective language you choose, the more persuasive you will be and the more linguistic power you will have. On the contrary, the more subjective you appear, the less persuasive you will be and the less linguistic power you will have.

The four samples used in this article are the pieces of the records of the cross-examination in court. They are chosen from Trial Techniques Thomas A. Maucet CITI Publishing House No.6 Edition. These four samples present four different types of cross-examinations in court, which are very good examples to present how the lawyers succeed in taking their tactics of examining to make the witness' testimony incredible for the jury.

\section{A. Analysis of Samples One and Two}

With the analysis of Sample One and Two, how the lawyer conducts his first tactic of discrediting the witness' perception successfully, making the witness' testimony not persuasive will be presented.

A common challenge to occurrence testimony focuses on the witness' ability and chance to observe the event involved. Showing that an event happened quickly and unexpectedly, that the witness was frightened or surprised, and that lighting was poor will make the jury realize that the circumstances under which the witness made the observation were not conducive to accuracy.

In the Sample One, the cross-examiner wants to establish that the witness did not actually see the pedestrian get hit by a car. Table1 and Table 2 are about the modality analysis of utterance of the lawyer and the witness, showing how many metaphorical modalities or non-metaphorical modalities used by the lawyer and the witness.

TABLE 1

MODALITY ANALYSIS OF UTTERANCES OF THE LAWYER

\begin{tabular}{|l|l|l|l|}
\hline No & Lawyer & Metaphorical modality & Non-metaphorical modality \\
\hline 1 & $\begin{array}{l}\text { In fact, you've driven through that intersection over } \\
\text { the past five years, haven't you? (3) }\end{array}$ & $\begin{array}{l}\text { In fact : objective : } \\
\text { high value }\end{array}$ & $\begin{array}{l}\text { usually: proposition } \\
\text { usuality: median value }\end{array}$ \\
\hline 2 & $\begin{array}{l}\text { You usually go through the intersection on your way } \\
\text { to and from work? (5) }\end{array}$ & $\begin{array}{l}\text { never: proposition } \\
\text { probability: high value }\end{array}$ \\
\hline 3 & $\begin{array}{l}\text { You never saw a pedestrian hit by a car there before, } \\
\text { did you? (9) }\end{array}$ & $\begin{array}{l}\text { always: proposition } \\
\text { usuality: high value }\end{array}$ \\
\hline 4
\end{tabular}

TABLE 2

MODALITY ANALYSIS OF UTTERANCES OF THE WITNESS

\begin{tabular}{|l|l|l|l|}
\hline No & Witness & $\begin{array}{l}\text { Metaphorical } \\
\text { modality }\end{array}$ & \\
\hline 1 & Probably.(8) & & $\begin{array}{l}\text { probably: proposition } \\
\text { probability :median value }\end{array}$ \\
\hline 2 & Yes, I'd say so. (14) & $\begin{array}{l}\text { I say so: subjective: } \\
\text { low value }\end{array}$ & $\begin{array}{l}\text { would: proposition } \\
\text { probability: median value }\end{array}$ \\
\hline 3 & I might have been. (18) & & $\begin{array}{l}\text { might: proposition } \\
\text { probability : low value }\end{array}$ \\
\hline
\end{tabular}

Table 1 and Table 2 compared, it is not difficult for us to find that the modality employed by the lawyer and the witness is very different, see Table 3 .

TABLE 3

STATISTIC RESULT OF MODALITY ANALYSIS OF UTTERANCES BY THE LAWYER AND THE WITNESS

\begin{tabular}{|c|c|c|c|c|c|c|c|c|c|}
\hline \multirow{3}{*}{ speaker $>$ modality } & \multicolumn{6}{|c|}{ Metaphorical modality } & \multirow{2}{*}{\multicolumn{3}{|c|}{$\begin{array}{l}\text { Non-metaphorical } \\
\text { modality }\end{array}$}} \\
\hline & \multicolumn{3}{|c|}{ subjective } & \multicolumn{3}{|c|}{ objective } & & & \\
\hline & low & med & high & low & med. & high & low & med. & high \\
\hline lawyer & - & - & - & - & - & 1 & - & 1 & 2 \\
\hline witness & 1 & - & - & - & - & - & 1 & 2 & - \\
\hline
\end{tabular}

1. Metaphorical modality system 
According to Halliday (1994), "Choice is meaning". Generally, if the speaker chooses more subjective modalities, that means he/she has a very clear attitude, dares to take the responsibility, but seems not to respect the fact totally. If the speaker chooses to use more objective modalities, he/she tends to make the fact clearer, respect the fact objectively, but seems not so responsible for what he/she says. From Table1 and Table2, we can see that in the cross-examination, the lawyer and the witness use metaphorical modality once respectively. But the lawyer's modality is objective with high value, while the witness' modality is subjective with low value. Here, the lawyer speaks more subjectively than the witness does, that is, the witness has more personal engagement.

\section{Non-metaphorical modality system}

As for the non-metaphorical modalities, choosing different values will have different meanings. High value reflects the speaker's firm certainty towards the state of affairs and makes the speaker more powerful in the conversation, while low value shows the speaker's uncertainty towards the fact and also makes the speaker inferior. In table 1 and table 2 , we can see that the lawyer employed non-metaphorical modalities three times-two of them are high value, (by $2 / 3$ ) one is median, no low value is used. The witness employed non-metaphorical three times-two are median value, one is low (by 1/3), and no high value. From different values the lawyer and the witness used, we can conclude that the lawyer is certain of the state of affairs, but the witness has more reservations. Thus the powerful position of lawyer is obviously reflected.

To sum up, by such a series of progressive questions, we have demonstrated that the witness was not expecting a crash and really did not notice anything until after hearing the sound of the crash. Therefore the lawyer can have his last question "so you didn't really see the pedestrian before the crash, did you?" The witness will invariably say "yes", or something even more damaging, which is needed in the lawyer's closing argument.

In Sample Two, a witness has testified to be driving down a street and observing a collision between two other cars. The cross-examination will show that the collision occurred quickly and unexpectedly, and that the witness was too far away to accurately observe what really happened.

The analysis of the utterance of the lawyer and the witness will be presented in Table 4 and Table 5 as follows:

TABLE 4

MODALITY ANALYSIS OF UTTERANCES OF THE LAWYER

\begin{tabular}{|c|c|c|c|}
\hline No. & Lawyer & $\begin{array}{l}\text { Metaphorical } \\
\text { modality }\end{array}$ & $\begin{array}{l}\text { Non-metaphorical } \\
\text { modality }\end{array}$ \\
\hline 1 & $\begin{array}{l}\text { So you were driving the way you usually would } \\
\text { just before the accident, weren't you?(11) }\end{array}$ & & $\begin{array}{l}\text { usually: proposition } \\
\text { usuality: median value } \\
\text { would: proposition } \\
\text { probability: median value }\end{array}$ \\
\hline 2 & $\begin{array}{l}\text { As you were driving toward the corner, you } \\
\text { couldn't see traffic on Maple other than at The } \\
\text { intersection, could you?(27) }\end{array}$ & & $\begin{array}{l}\text { could: proposition: } \\
\text { probability: low value }\end{array}$ \\
\hline 3 & $\begin{array}{l}\text { So you couldn't see the two cars involved in the } \\
\text { accident until they were actually in the } \\
\text { intersection, could you?(31) }\end{array}$ & & $\begin{array}{l}\text { could: proposition: } \\
\text { probability: low value }\end{array}$ \\
\hline 4 & $\begin{array}{l}\text { There were probably cars Going in both } \\
\text { directions on Elm Street, weren't there? (39) }\end{array}$ & & $\begin{array}{l}\text { probably: proposition } \\
\text { probability: median value }\end{array}$ \\
\hline
\end{tabular}

TABLE 5

MODALITY ANALYSIS OF UTTERANCES OF THE WITNESS

\begin{tabular}{|l|l|l|l|}
\hline No. & Mitness & $\begin{array}{l}\text { Metaphorical } \\
\text { modality }\end{array}$ & $\begin{array}{l}\text { Non-metaphorical } \\
\text { modality }\end{array}$ \\
\hline 1 & I think so.(18) & $\begin{array}{l}\text { I think: subjective: } \\
\text { low value: }\end{array}$ & $\begin{array}{l}\text { I guess: subjective: } \\
\text { low value }\end{array}$ \\
\hline 2 & I guess so.(22) & $\begin{array}{l}\text { probably: proposition } \\
\text { probability: median value }\end{array}$ & \\
\hline 3 & Probably. (40) & $\begin{array}{l}\text { That's possible: } \\
\text { objective: low value }\end{array}$ & $\begin{array}{l}\text { That's possible: } \\
\text { objective: low value } \\
\text { I'm not sure: subjective: low value }\end{array}$ \\
\hline 5 & That's possible.(42) & $\begin{array}{l}\text { That's possible, but I'm } \\
\text { not sure.(44) }\end{array}$
\end{tabular}

For clearer analysis, we present the statistic result of modality used by the lawyer and the witness in Table 6.

TABLE 6

STATISTIC RESULT OF MODALITY ANALYSIS OF UTTERANCES BY THE LAWYER AND THE WITNESS

\begin{tabular}{|c|c|c|c|c|c|c|c|c|c|}
\hline \multirow{3}{*}{$\mathrm{P}_{\text {speaker }}$ modality } & \multicolumn{6}{|c|}{ Metaphorical modality } & \multirow{2}{*}{\multicolumn{3}{|c|}{$\begin{array}{l}\text { Non-metaphorical } \\
\text { modality }\end{array}$}} \\
\hline & \multicolumn{3}{|c|}{ subjective } & \multicolumn{3}{|c|}{ objective } & & & \\
\hline & low & med. & high & low & med. & high & low & med. & high \\
\hline lawyer & - & - & - & - & - & - & 2 & 3 & - \\
\hline witness & 3 & - & - & 2 & - & - & - & 1 & - \\
\hline
\end{tabular}




\section{Metaphorical modality system}

From table 6, we can see that the lawyer does not choose metaphorical modalities while the witness uses metaphorical modalities with low value fives time, no median value and high value. That is to say, the witness is not so certain of the state of affairs. Besides, among the fives metaphorical modalities he used, three are subjective $(60 \%)$ and only two are objective (40\%). The subjective modalities go beyond the objective modalities by $20 \%$. Here, we can conclude that the witness had too much personal comment on the fact, and made himself less powerful in the position, thus less persuasive.

\section{Non-metaphorical modality system}

According to table 6, the lawyer employs the non-metaphorical modalities for five times, three are median, two are low, and no high value modalities are used. However, the witness uses only one non-metaphorical modality with median value. From the percentage, we can find that low value modalities in the lawyer's utterances are more than those in the witness' by $40 \%$, which also reflects his uncertainty. This does not mean that he is unable to keep a firm grasp on the situation of the cross-examination. It is due to his position in the cross-examination as an examination and the way he has to put forward his question. To his questions "As you were driving toward the corner, you couldn't see traffic on Maple other than at the intersection, could you?(27)" and "So you couldn't see the two cars involved in the accident until they were actually in the intersection, could you?" (31), the witness answers: "No." And the witness' answer was very positive to the lawyer's final purpose, which is to prove that the collision occurred quickly and unexpectedly, and that the witness was too far away to accurately observe what really happened. Medina value modalities used by the witness are more than those by the lawyer by $40 \%$. But this does not mean that he has the grasp of the situation. It is only because he, as the examined, has to do to answer the question from the lawyer: "There were probably cars going in both directions on Elm Street, weren't there?" (39) With "probably", which also contribute to the lawyer's purpose? Now we can see that the lawyer still appeared more powerful in this conversation.

\section{Inner-sentence modality accumulation}

When there are two or more modalities occurring within one sentence or a clause complex, we call this phenomenon inner-sentence modality accumulation. There are two kinds of common modality accumulations. They are subjective metaphorical modality plus non-metaphorical modality and objective metaphorical modality plus non-metaphorical modality. From table4, we can see that the lawyer used one inner-sentence modality accumulation. "So you were driving the way you usually would just before the accident, weren't you?" (11) There appears two modalities, both of median value. From table5, we can see that the witness also uses one inner-sentence modality accumulation. "That's possible, but I'm not sure." (44) There are two modalities, both of low value. Both the lawyer and the witness have the uncertainty. The difference lies in that the lawyer's uncertainty is to tempt the witness to tell the truth, while the witness is not sure of the fact.

Through this cross-examination, we are convinced that the witness was such a good distance from the accident so that she could not see the cars involved until they were in the intersection, and probably had traffic blocking her view at the critical moments. That will lead the jury to believe that her observations are not as reliable as they first appeared to be.

\section{B. Analysis of Sample Three}

For the second tactic of discrediting the witness' memory, the lawyer does a very good job of putting questions for the witness to answer, and finally proves that the witness does not have a clear memory with a good command of modality.

The witness' ability to recall details of an event, and his efforts to record or preserve these details, are usually important considerations. Even where the witness had a very good opportunity to observe an event accurately, the time between an even and the witness' testimony in court may be substantial. When this happens, cross-examinations often point out that the witness has forgotten details without any efforts to record them, or even confuses this event with other similar ones. Using modalities in a proper way can help the lawyer a lot, on the way to achieving this goal.

In the Sample Three, Plaintiff's secretary has testified that she mailed to the defendant a letter that accepted a previous offer the defendant made to the plaintiff. The defendant has denied receiving Plaintiff's letter. The cross-examination will demonstrate that because the secretary types and processes so many letters, she can't possibly remember how this particular letter was handled.

Table 7 and Table 8 show the modality analysis of utterance of the lawyer and the witness. 
TABLE 7

MODALITY ANALYSIS OF UTTERANCE OF THE LAWYER

\begin{tabular}{|l|l|l|l|}
\hline No. & Lawyer & $\begin{array}{l}\text { Metaphorical } \\
\text { modality }\end{array}$ & Non-metaphorical modality \\
\hline 1 & So you would type approximately 25 letters a week, right?(7) & & $\begin{array}{l}\text { would: proposition: } \\
\text { probability: median value }\end{array}$ \\
\hline 2 & That would make about 100 each month?(9) & would: proposition: probability: median value \\
\hline 3 & $\begin{array}{l}\text { This means that you've probably typed over 5,000 letters for } \\
\text { Mr. Doe since you started working For him, correct?(13) }\end{array}$ & $\begin{array}{l}\text { probably: proposition: } \\
\text { probability: median value }\end{array}$ \\
\hline 4 & $\begin{array}{l}\text { Ms. Jones, now and then Mr. Doe will make changes on a } \\
\text { letter you've given him to sign, won't he?(15) }\end{array}$ & $\begin{array}{l}\text { will: proposition: } \\
\text { probability: median value }\end{array}$ \\
\hline 5 & $\begin{array}{l}\text { In those instances you'll type a new draft of the letter?(17) } \\
\text { will: proposition: } \\
\text { probability: median value }\end{array}$ & $\begin{array}{l}\text { will: proposition: } \\
\text { probability: median value }\end{array}$ \\
\hline 6 & $\begin{array}{l}\text { Now and then Mr. Doe will decide not to send a letter you've } \\
\text { typed at all, won't he?(21) }\end{array}$ & $\begin{array}{l}\text { will: proposition: } \\
\text { probability: median value }\end{array}$ \\
\hline 7 & $\begin{array}{l}\text { Every now and then Mr. Doe will keep a letter on his desk that } \\
\text { you've typed, won't he?(25) }\end{array}$ & $\begin{array}{l}\text { probably: proposition: } \\
\text { probability: median value }\end{array}$ \\
\hline 8 & $\begin{array}{l}\text { Every now and then you've probably had to remind him to } \\
\text { send a letter out, haven't you?(27) } \\
\text { Ms. Jones, as you sit here now, you can't remember which } \\
\text { letters over the past five years you've retyped, can you?(29) }\end{array}$ & & can:proposition: probability: low value \\
\hline 9
\end{tabular}

TABLE 8

MODALITY ANALYSIS OF UTTERANCES OF THE WITNESS

\begin{tabular}{|c|c|c|c|}
\hline No. & witness & $\begin{array}{l}\text { Metaphorical } \\
\text { modality }\end{array}$ & Non-metaphorical modality \\
\hline 1 & $\begin{array}{l}\text { It varies, of course, but it's probably around } 5 \text { a } \\
\text { day.(6) }\end{array}$ & & $\begin{array}{l}\text { probably: proposition: } \\
\text { probability: median value }\end{array}$ \\
\hline 2 & I guess so.(12) & $\begin{array}{l}\text { I guess so: } \\
\text { subjective: low value }\end{array}$ & \\
\hline 3 & Probably.(14) & & $\begin{array}{l}\text { probably: proposition: } \\
\text { probability: median value }\end{array}$ \\
\hline 4 & Oh, perhaps once or twice a week.(20) & & $\begin{array}{l}\text { perhaps: proposition: } \\
\text { probability: low value }\end{array}$ \\
\hline 5 & Oh, maybe a couple of times a month.(24) & & $\begin{array}{l}\text { maybe: proposition: } \\
\text { probability: low value }\end{array}$ \\
\hline
\end{tabular}

To make it clearer, we made Table 9 to demonstrate the statistic result of modality analysis of utterances by the lawyer and the witness.

TABLE 9

STATISTIC RESULT OF MODALITY ANALYSIS OF UTTERANCES BY THE LAWYER AND THE WITNESS

\begin{tabular}{|c|c|c|c|c|c|c|c|c|c|}
\hline \multirow{3}{*}{ speaker modality } & \multicolumn{6}{|c|}{ Metaphorical modality } & \multirow{2}{*}{\multicolumn{3}{|c|}{$\begin{array}{l}\text { Non-metaphorical } \\
\text { modality }\end{array}$}} \\
\hline & \multicolumn{3}{|c|}{ subjective } & \multicolumn{3}{|c|}{ objective } & & & \\
\hline & low & med & high & low & med. & high & low & med. & high \\
\hline lawyer & - & - & - & - & - & - & 1 & 7 & - \\
\hline witness & 1 & - & - & - & - & - & 2 & 2 & - \\
\hline
\end{tabular}

\section{Metaphorical modality system}

From table 9, we can see that the lawyer did not choose metaphorical modalities while the witness uses metaphorical modalities of low value for only one time, no median value and high value. That is to say, the witness is not so certain of the state of affairs. Besides, the metaphorical modality the witness used is subjective with low value: "I guess so" (12), which makes him appear less certain and less persuasive.

\section{Non-metaphorical modality system}

According to table 9, the lawyer employed the non-metaphorical modalities eight times-seven are with median value, one is low, and no high value modalities are used. However, the witness uses four non-metaphorical modalities-two are median value another two are low value. From the percentage, we can find that low value modalities in the witness' utterances are more than those in the lawyer's by $38 \%$, which also reflects his uncertainty. In this cross-examination, neither the lawyer nor the witness employed high value modalities, which demonstrates that both the lawyer and the witness have their uncertainty.

As for the lawyer, he employs seven modalities with median value seven times. In the first three times-sentence (7), (9) and (13), the lawyer focuses on the numbers of the letters typed by the witness in a week, each month and since she started working for her boss. Undoubtedly, they are large numbers. The lawyer employs such median value modalities in order to make the witness admit that she had too many letters to type.

In the other four times of modalities employed by the lawyer, sentence (15), (17),(21), (25) and (27), the lawyer points out that the letters having been prepared does mean that they will be sent: some will be changed, some retyped, some not sent, some kept on the boss' desk and so on. With the modalities with median value, the lawyer succeeded in making the witness agree that she was in such a confusing condition, that it is difficult for her to have a clear memory of the letters she typed. Consequently, in the sentence (29) with low value modalities, the lawyer leaded the witness to 
answer his question "you can't remember which letters over the past five years you've retyped, can you?" (29) With "No."

As for the witness, she employed two median value modalities and two low value modalities which reflect that she is not certain about the fact and doesn't have a very clear memory. Because the purpose of this cross-examination is to suspect the witness' ability to remember details, the witness will be inferior in this conversation.

Finally, the lawyer drew a conclusion "It's simply a case of too many years and too many letters, isn't it?" (35). the witness answered "Yes" without any other choices.

\section{Analysis of Sample Four}

In sample Four, the lawyer is taking the tactic of discrediting the witness' ability to communicate to prove that the witness cannot re-create a picture of what happened to the jury accurately. Modality also plays a vital role.

Another method of discrediting testimony is to test the witness' ability to communicate. It will do much good to the opposite side, if a witness has observed an event, remember what happened, yet is unable to describe the event logically and accurately to the jury. A common cross-examination technique is to examine the witness' ability to describe directions and details and to estimate distance and time, to demonstrate that the witness cannot re-create a picture of what happened to the jury accurately.

In sample Four, a witness has testified to the details of a collision and the time and distances involved. The cross-examination will show that the descriptions, time, and distances are not accurate or reliable. In Table 10 and Table 11 , we can have a clear idea of different modality employed by the lawyer and the witness in this cross-examination.

TABLE 10

MODALITY ANALYSIS OF UTTERANCE OF THE LAWYER

\begin{tabular}{|l|l|l|l|}
\hline No & Lawyer & $\begin{array}{l}\text { Metaphorical } \\
\text { modality }\end{array}$ & Non-metaphorical modality \\
\hline 1 & $\begin{array}{l}\text { From your porch you could see both cars } \\
\text { involves in the accident, right? (2) }\end{array}$ & $\begin{array}{l}\text { could: proposition: } \\
\text { probability: median value }\end{array}$ \\
\hline 2 & $\begin{array}{l}\text { Mr. Jones, could you estimate the distance form } \\
\text { the witness stand to the doors at the back of the } \\
\text { courtroom?(18) }\end{array}$ & $\begin{array}{l}\text { could: proposal: } \\
\text { obligation: low value }\end{array}$ \\
\hline 3 & $\begin{array}{l}\text { Your Honor, may the record reflect the distance } \\
\text { is actually 38 feet? (20) }\end{array}$ & $\begin{array}{l}\text { may: proposition: } \\
\text { probability: low value }\end{array}$ \\
\hline
\end{tabular}

TABLE 11

MODALITY ANALYSIS OF UTTERANCE OF THE WITNESS

\begin{tabular}{|l|l|l|l|}
\hline No. & witness & $\begin{array}{l}\text { Metaphorical } \\
\text { modality }\end{array}$ & $\begin{array}{l}\text { Non-metaphorical } \\
\text { modality }\end{array}$ \\
\hline 1 & Well, it's a long driveway, so it's Maybe 100 feet.(9) & & $\begin{array}{l}\text { maybe: proposition: } \\
\text { probability: low value }\end{array}$ \\
\hline 2 & Maybe four seconds or so.(11) & $\begin{array}{l}\text { maybe: proposition: } \\
\text { probability: low value }\end{array}$ & $\begin{array}{l}\text { maybe: proposition: } \\
\text { probability: low value }\end{array}$ \\
\hline 3 & Oh, maybe 500 feet away.(15) & $\begin{array}{l}\text { maybe: proposition: } \\
\text { probability: low value }\end{array}$ \\
\hline 4 & Maybe 20 seconds or so. (17) & & \\
\hline
\end{tabular}

Table 12 present us the statistic result of modality analysis of utterances by the lawyer and the witness.

TABLE 12

STATISTIC RESULT OF MODALITY ANALYSIS OF UTTERANCES BY THE LAWYER AND THE WITNESS

\begin{tabular}{|c|c|c|c|c|c|c|c|c|c|}
\hline \multirow{3}{*}{ speaker modality } & \multicolumn{6}{|c|}{ Metaphorical modality } & \multirow{2}{*}{\multicolumn{3}{|c|}{$\begin{array}{l}\text { Non-metaphorical } \\
\text { modality }\end{array}$}} \\
\hline & \multicolumn{3}{|c|}{ subjective } & \multicolumn{3}{|c|}{ objective } & & & \\
\hline & low & Med. & high & low & Med. & high & low & Med. & high \\
\hline lawyer & - & - & - & - & - & - & 2 & 1 & - \\
\hline witness & - & - & - & - & - & - & 4 & - & - \\
\hline
\end{tabular}

\section{Non-metaphorical system}

According to table 12, it is not difficult for us to see that neither the lawyer nor the witness employed metaphoric modality system. However, from the non-metaphorical modalities they chose, we can also infer the different linguistic position of them. The lawyer used non-metaphorical modalities three times-two are of low value, one median value. But it does mean that the lawyer lost the grasp in the cross-examination. If we examine the modalities employed by the lawyer in detail, we can find the lawyer use proposal twice in sentences (18) and (20), but witness does not use it even once. Proposal means that the speaker requests orders the hearer to do something, so the speaker is more powerful than the hearer. On the other hand, the modalities employed by the witness are all of low value, which reflects that the witness is totally not certain of his own abilities of measuring the distance and the time: sentence (9), (11), (15), and (17). What's more, the witness actually failed in estimating distance by saying: "that's about 25 feet." In fact, it is 38 feet. 
As a matter of fact, every lawyer handling automobile cases learns that $15 \mathrm{mph}=22 \mathrm{ft}$./sec. The witness said the defendant's car traveled 100 feet in 4 seconds, or over 15mph. As plaintiff, the lawyer can argue that this was an excessive rate of speed for a driveway. The witness also stated that the plaintiff's car traveled 500 feet in 20 seconds, or less than 20mph. The lawyer can also easily argue that this was a safe speed to be traveling on a residential street. This type of cross-examination, pinning the witness down to specific estimates of distances, time, and speed, is a common technique in accident cases. After that, the lawyer can demonstrate that this witness is an unreliable source of information, because he is not capable of accurately.

From the above analysis, we can see that the lawyers discredit or limit the witness' testimony successfully by discrediting the witness' perception, memory and ability to communicate. To fulfill their purposes, the lawyers need to have a good command of their specialty and language skills. As for the language skills, the ability to rein the use of modality helps them a lot.

It is not difficult for us to know that among the samples, the lawyers tend to employ more high value and objective modalities than the witnesses do. It demonstrates that the lawyers speak more objectively and with more certainty. On the contrary, the witnesses are more likely to engage personally and more subjectively, thus their testimony does not have much reliability for the jury. In the courtroom, being objective and more certain means to prevail and have more persuasion. Those who can rein the use of modality are more powerful and persuasive than those who cannot. So from the perspective of modality, the lawyers in the samples are much more powerful than the witnesses.

\section{CONCLUSION}

This article expands the application of Systemic Functional Linguistics to the conversation analysis in the legal field, and the basic principles and methodologies of Systemic Functional Linguistic open a new horizon for courtroom discourse analysis. From the modality perspective, different types, orientations and values of modality will have influence on the speaker's linguistic position and reliability for the jury.

According to the analysis of the four samples, we can find that there is great difference between the lawyer's modality and the witness'. For succeeding in taking the three tactics of examining, the lawyers are very careful in choosing their words and questions. By comparison, the lawyers tend to employ more high and median modalities such as never, would, will, usually and so on, but no subjective modalities come into their utterances. That means the lawyers speak objectively and with great certain and less personal engagement. However, the witnesses are more likely to use more low value modalities, such as maybe, perhaps, could and so on and they are quite liberal with the employment of subjective metaphorical modalities with low such as "I think", "I guess", "I am not sure" and so on. Besides, the witnesses employ the objective metaphorical modalities with low value like "that's possible". This shows that the witnesses like to speak subjectively, with less certainty and more personal engagement. In the courtroom, being objective and certain means being more powerful in the linguistic position and more persuasive for the jury. Otherwise, you will seem less convincing.

The result of the analysis gives suggestions for the lawyers and the witnesses to examine or reply in a successful way. Additionally, the debaters and the lecturers should be careful in choosing modality if they want to be more persuasive for the audience. As for the ordinary people in communications, the choice of different modality will give others different impression, which influences the chance of a successful communication.

\section{APPENDIX}

\section{Sample One:}

Q: You're familiar with the intersection of North and Clark? (1)

A: Yes. (2)

Q: In fact, you've driven through that intersection over the past five years, haven't you? (3)

A: Yes. (4)

Q: You usually go through the intersection on you way to and from work? (5)

A: Yes. (6)

Q: You were about one-half block from the corner when it happened, isn't that so? (7)

A: Yes. (8)

Q: It's fair to say that you weren't expecting an accident that day, isn't it? (9)

A: Yes. (10)

Q: So you were driving the way you usually would just before the accident, weren't you? (11)

A: Yes. (12)

Q: You had a passenger in the car? (13)

A: Yes. (14)

Q: You were talking with him while driving? (15)

A: Yes. (16)

Q: Ms. Jones, each block in this city is one-eighth of a mile long, isn't it? (17)

A: I think so. (18) 
Q: So each block is about 600 feet long, isn't it? (19)

A: That sounds about right. (20)

Q: This means that you were about 300 feet from the corner when the accident happened, weren't you? (21)

A: I guess so. (22)

Q: Three hundred feet is the length of a football field, isn't it? (23)

A: Yes. (24)

Q: Both Maple and Elm have building on both sides of the street, don't they? (25)

A: Yes. (26)

Q: As you were driving toward the corner, you couldn't see traffic on Maple other than at the intersection, could you? (27)

A: No. (28)

Q: That's because the building was blocking your view? (29)

A: Yes. (30)

Q: So you couldn't see the two cars involved in the accident until they were actually in the intersection, could you? (31)

A: No. (32)

Q: Ms. Jones, there was other traffic on Elm Street as well as Maple that morning, wasn't there. (33)

A: Yes. (34)

Q: You were watching that other traffic as you were driving? (35)

A: Yes. (36)

Q: Elm Street has a good amount of traffic during the rush hour, doesn't it? (37)

A: Yes. (38)

Q: There were probably cars going in both directions on Elm Street, weren't there? (39)

A: Probably. (40)

Q: Some of those cars were in your lane, while others were in the opposite lane, weren't they? (41)

A: That's possible. (42)

Q: And some of the cars were in front of you, while others were behind you, weren't they? (43)

A: That's possible, but I'm not sure. (44)

\section{Sample Two:}

Q: Ms. Jones, Maple Avenue is a north-South Street and Elm Street runs east-west, correct? (1)

A: Yes. (2)

Q: The accident you say you observed was at that intersection? (3)

A: Yes. (4)

Q: When the accident happened, you were driving toward the intersection on Elm Street, correct? (5)

A: Yes. (6)

Q: You were about one-half block from the corner when it happened, isn't that so? (7)

A: Yes. (8)

Q: It's fair to say that you weren't expecting an accident that day, isn't it? (9)

A: Yes. (10)

Q: So you were driving the way you usually would just before the accident, weren't you? (11)

A: Yes. (12)

Q: You had a passenger in the car? (13)

A: Yes. (14)

Q: You were talking with him while driving? (15)

A: Yes. (16)

Q: Ms. Jones, each block in this city is one-eighth of a mile long, isn't it? (17)

A: I think so. (18)

Q: So each block is about 600 feet long, isn't it? (19)

A: That sounds about right. (20)

Q: This means that you were about 300 feet from the corner when the accident happened, weren't you? (21)

A: I guess so. (22)

Q: Three hundred feet is the length of a football field, isn't it? (23)

A: Yes. (24)

Q: Both Maple and Elm have building on both sides of the street, don't they? (25)

A: Yes. (26)

Q: As you were driving toward the corner, you couldn't see traffic on Maple other than at the intersection, could you? (27)
A: No. (28)
Q: That's because the building was blocking your view? (29)
A: Yes. (30) 
Q: So you couldn't see the two cars involved in the accident until they were actually in the intersection, could you? (31)

A: No. (32)

Q: Ms. Jones, there was other traffic on Elm Street as well as Maple that morning, wasn't there. (33)

A: Yes. (34)

Q: You were watching that other traffic as you were driving? (35)

A: Yes. (36)

Q: Elm Street has a good amount of traffic during the rush hour, doesn't it? (37)

A: Yes. (38)

Q: There were probably cars going in both directions on Elm Street, weren't there? (39)

A: Probably. (40)

Q: Some of those cars were in your lane, while others were in the opposite lane, weren't they? (41)

A: That's possible. (42)

Q: And some of the cars were in front of you, while others were behind you, weren't they? (43)

A: That's possible, but I'm not sure. (44)

\section{Sample Three:}

Q: Ms. Jones, you've been Mr. Doe's secretary for some five years now? (1)

A: Yes. (2)

Q: The events to which you just testified took place almost three years ago? (3)

A: Yes. (4)

Q: How many letters, on the average, do you type during a working day? (5)

A: It varies, of course, but it's probably around 5 a day. (6)

Q: So you would type approximately 25 letters a week, right? (7)

A: Approximately. (8)

Q: That would make about 100 each month? (9)

A: Approximately. (10)

Q: An over1, 000 each year? (11)

A: I guess so. (12)

Q: This means that you've probably typed over 5,000 letters for Mr. Doe since you started working for him, correct?

(13)

A: Probably. (14)

Q: Ms. Jones, now and then Mr. Doe will make changes on a letter you've given him to sign, won't he? (15)

A: Yes. (16)

Q: In those instances you'll type a new draft of the letter? (17)

A: Yes. (18)

Q: How often does that happen? (19)

A: Oh, perhaps once or twice a week. (20)

Q: Now and then Mr. Doe will decide not to send a letter you've typed at all, won't he? (21)

A: Yes. (22)

Q: How often does that happen? (23)

A: Oh, maybe a couple of times a month. (24)

Q: Every now and then Mr. Doe will keep a letter on his desk that you've typed, won't he? (25)

A: Yes. (26)

Q: Every now and then you've probably had to remind him to send a letter out, haven't you? (27)

A: Yes. (28)

Q: Ms. Jones, as you sit here now, you can't remember which letters over the past five years you've retyped, can you?(29)

A: No. (30)

Q: Or which letters Mr. Doe decided not to mail? (31)

A: No. (32)

Q: Or which letters you had to remind him to put in the mail? (33)

A: No. (34)

Q: It's simply a case of too many years and too many letters, isn't it? (35)

A: Yes. (36)

\section{Sample Four:}

Q: Mr. Jones, you were sitting on the porch of your house when the accident happened? (1)

A: Yes. (1)

Q: From your porch you could see both cars involves in the accident, right? (2)

A: Yes. (3)

Q: The impact between the two cars happened right in front of your house? (4) 
A: Yes. (5)

Q: The defendant was pulling out of his driveway across the street from you, right? (6)

A: Yes. (7)

Q: How long is that driveway? (8)

A: Well, it's a long driveway, so it's maybe 100 feet. (9)

Q: How long did you estimate it took for the car to go the length of the driveway? (10)

A: Maybe four seconds or so. (11)

Q; The Plaintiff's car on the street going toward you was moving at about $40 \mathrm{mph}$, is that your estimation?(12)

A: Yes. (13)

Q: How far away from you was the plaintiff's car when you first saw it? (14)

A: Oh, maybe 500 feet away. (15)

Q: And how long did it take the Plaintiff's car to travel 500 feet? (16)

A: Maybe 20 seconds or so. (17)

Q: Mr. Jones, could you estimate the distance form the witness stand to the doors at the back of the courtroom? (18)

A: well, that's about 25 feet. (19)

Q: Your Honor, may the record reflect the distance is actually 38 feet? (20)

Court: It may ---- we've measured that before. (21)

\section{REFERENCES}

[1] Brown, G. \& Yule. (1983). Discourse Analysis. Cambridge: Cambridge University Press.

[2] Chang Chenguang. (2001). Interpersonal Metaphors in English. Foreign Languages and Their Teaching 7, 6-8.

[3] Conley, John M., and William M. O'Barr. (1998). Just Words: Law, Language and Power. Chicago: University of Chicago Press.

[4] Eggins, S. \& D.Slade. (1997). Analyzing Casual Conversation. London: Cassel.

[5] Gibbons, John. (1994). Language and the law. London: Longman.

[6] Halliday, M.A.K. (1985). An Introduction to Functional Grammar. London: Edward Arnold.

[7] Halliday, M.A.K. \& Hasan R. (1989) Language, Context and Text. Oxford: Oxford University Press.

[8] Hu Zhuanglin. (2001). Linguistics: A Course Book (2nd Ed.). Beijing: Beijing University Press.

[9] Hu Zhuanglin, Jiang Wangqi. (2002). Linguistics: An Advanced Course Book. Beijing: Beijing University Press.

[10] Kress, G.R., Halliday, M.A.K. (1975). System and Function in Language. Oxford: Oxford University Press.

[11] Lyons, J. (1995). Linguistic Semantics: An Introduction. Cambridge: Cambridge University Press.

[12] Simpson, P. (1993). Language, Ideology and Point of Few. London and New York: Routledge.

[13] Stygall, Gail. (1994). Trial Language Discourse: Text and Talk. Washington D.C.: Georgetown University Press.

[14] Thomas A. Maucet. (2002). Trial Techniques (6th Ed). New York: Aspen Law \& Business.

[15] Thompson, G. (1996/2000). Introducing Functional Grammar. Beijing: Foreign Language Teaching and Research Press.

[16] Woods, A. et al. (2000). Statistics in Language Studies. Beijing: Foreign Language Teaching and Research Press.

[17] Wang Zhenhua. (2004). Power in Cross-examination: An "Modality" Analysis of a Segment of Courtroom Discourse of O. J. Simpson Case. Foreign Language Research 3, 51-59.

Jiezhen Dong, born in 1978, Guangdong province, China, is currently a lecture of English at Guangdong Pharmaceutical University, Guangzhou, China. She attained her MA degree in English Language and Literature from Sun Yat-sen University, China. She has interests in English teaching and system-functional linguistics study. 